\title{
SHADOW-READING STRATEGY EFFECT ON EFL LISTENING COMPREHENSION SKILLS AND MOTIVATION
}

\author{
Faten A. Zahran \\ Lecturer of Curriculum \& Instruction, Horus University in Egypt
}

\begin{abstract}
The aim of this research was to determine the effectiveness of the shadow reading strategy on developing EFL secondary school students listening comprehension skills and motivation. Questions formulated to achieve the aim of the study focused on: (1) Determining listening comprehension skills suitable for the EFL secondary school students. (2) Finding out differences in listening comprehension test regarding experimental and control group. (3) Finding out differences in listening motivation scale scores regarding experimental and control group. Three instruments -designed by the researcher- that include: (listening comprehension skills checklist, listening comprehension skills test and listening motivation scale) were used for data collection. Results revealed that the regular method used to teach listening is not as significant as the shadow reading strategy that develop listening comprehension skills and motivation. Students of experimental group outperformed their counterparts of the control group in listening comprehension skills and motivation scores.
\end{abstract}

Key Words: EFL listening comprehension skills, motivation, shadow reading strategy.

\section{Introduction:}

Good readers have a tendency to be good listeners and vice versa. Behavioral studies have revealed that listening comprehension and reading are associated and accompanying skills. Skilled readers comprehend and reclaim phonological information faster (Booth, Perfetti, \& MacWhinney, 1999; Booth, Perfetti, MacWhinney, \& Hunt, 2000). Listening takes place to accomplish definite aims, whether educational or social; comprehending the main thoughts and conceptions, listening for specifics, and constructing implications (Brown, 2006,). Students' capability to interpret the speaker's message determines their listening comprehension skills. Since listening comprehension rely on speakers' fluency, listeners may possibly inquire for retelling. Accordingly, listening is to recognize the reader's intonation, pronunciation, syntax and expressions to understand what is conveyed by the reader. Furthermore, listening can help students accomplish educational goals (Armstrong
\& Rentz, 2002). Though, Goh (2008) states that listening skill has not received sufficient attention. Listening skills are a demanding charge for all learners. Consequently, teachers are recommended to encourage students to take part in their own listening improvement (Goh and Taib, 2006).

Students have various capabilities, potentials, motivation level and various educational techniques. Furthermore, the methodology of learning has changed from teacher-centered to student-centered which implies giving opportunity for students to be involved in educational process (Goodnough, 2001; Kallenback \& Viens, 2002; Haley, 2004; Scapens, 2007). Accordingly, for developing listening skills, students should be motivated to read, listen, react and discuss the topics through peer interaction since educational methods that manage the manner students think and feel are operative techniques for developing students' motivation that in turn improve their academic success (Kok, 2010). Among these techniques is shadow reading. 
Shadowing allows learners to retell, recite and take part in imitation practice as well, a procedure that is central to educational process. According to Vygotskyan social cognitive theory, imitation is considered primary element of improvement process (Vygotsky 1986). Yet, how imitation process can be achieved in language curriculums still requires further research.

Shadow-reading is an activity in which students take part in reading, retelling and summarizing (Guerrero \& Commander, 2013). Murphey (2001) considers that shadowing is a step between being othercontrolled and self-controlled, as students repeat the reader language, they become able to control their output. Shadow reading is different from just listening to the record of a lesson without interacting (Anderson, 2009, Nakanishi \& Ueda, 2011). Instead, it is a version of interactive imitation (Murphey, 2000, 2001), a strategy in which students comprehend the readers' oral language to repeat, summarize, comment and help each other form a meaning for the repeated text. In this study shadow reading was employed to find out how it could enhance students' listening comprehension. Additionally, students' enthusiasm and motivation are essential keys for foreign language development. Increasing students' motivation can have a positive impact on developing their listening skills that in turn develop their EFL learning. The insufficiency of listening opportunity inside classrooms has impacts on EFL students. Motivation encourages students to make use of listening opportunities (Bernaus and Gardner, 2008 and Noles, 2013). This study aimed to investigate the role can shadow reading play in the advancement of listening and motivation among EFL secondary school students.

\section{The Context of the Problem}

In spite of the Egyptian Ministry of Education efforts to present new EFL syllabuses based on recent methods of curriculum design and teaching strategies, students face challenges in developing EFL listening comprehension as they are hardly given sufficient opportunity to listen to English language. Furthermore, most of schools do not give the same care for listening as the other skills. Teachers only teach listening in few minutes in a lesson that assures the idea of listening as a neglected skill and this negatively influences student's listening achievement. (Abdel-Latif, 2002; Abu-Essa, 2005; Phuong 2011; Myxter, 2014). Osada (2004) stated that listening skills don't obtain academic attention. It is dealt with as passive skills that would be improve without academic training. As the educational process focus on teaching reading, vocabulary and grammar while listening is not of an important concern to most schools programs, EFL students have difficulties in listening comprehension (Hamouda, 2013). Moreover, according to (Ryan \& Deci, 2000 and Motlhaka, 2012) motivation was believed to be responsible for EFL learning development process and listening in particular which is not considered a major element for many teachers inside the classroom.

In view of the many challenges facing EFL secondary school students in developing listening comprehension skills and motivation, the current study leading aim is to provide evidence for efficiency of shadow reading on increasing EFL students listening comprehension skills and motivation.

\section{Statement of the Problem}

Secondary school students lack the ample training needed for effective listening comprehension and motivation. Therefore, the researcher proposes that using shadow reading strategy might develop students' listening comprehension and motivation.

\section{Questions}

The study attempts to answer the following questions: 
1- What are the listening comprehension skills suitable for secondary school students?

2-What are the characteristics of shadow reading strategy that helps developing listening comprehension skills and motivation?

3- What is the effect of using shadow reading in developing secondary school students listening comprehension skills?

4- What is the effect of using shadow reading in developing secondary school students' listening comprehension motivation?

\section{Significance}

The study attempts to achieve the following:

1. Training students on new strategies for developing listening comprehension skills.

2. Directing the attention of researchers, teachers, course designers and curriculum developers to the importance of using shadow reading strategy.

3. Encouraging researchers to expand their research on using shadow reading strategy in process of EFL teaching.

\section{Hypotheses}

1. There is statistically significant difference between the mean score of experimental group and the control group on the post- administration of listening skills test favoring the experimental one.

2. There is statistically significant difference between the mean score of the experimental group on the pre- and post- administration of listening skills favoring the post administration scores.

3. There is statistically significant difference between the mean score of experimental group and the control group on the post- administration of listening motivation scale favoring the experimental one.

4. There is statistically significant difference between the mean score of the experimental group on the pre- and post- administration of listening motivation scale favoring the post administration scores.

\section{Delimitations}

1. A sample of the first year of secondary school students from Mansoura Elthanwya Elgdeeda secondary school for girls at Dakahlia governorate.

2. Six listening comprehension skills that include: (retaining relevant points through note-taking, identifying the reader's (shadower) feeling, identifying the main ideas, asking questions to clarify the meaning, making correct inferences from what is listened to, distinguishing between literal and implied).

\section{Review of Literature}

The degree to which shadowing can develop listening comprehension has been a matter of argument currently. Likewise, comprehension development has been a great concern for EFL language researchers (Buck, 2003\& Kern, 2000). In the process of listening, students use different intellectual processes in order to understand what they listen to. The intellectual processes that students use to give a meaning to verbal English can be generally called listening comprehension techniques (Coskun 2010). Shadow listening, the main educational technique used in this research, was adapted from Murphey's (2001) conversational shadowing, a strategy that based on repeating whether mutely or loudly what readers say. Tannen (2007) considers that shadowing is a student natural desire to retell and imitate.

\section{Listening Comprehension Skills}

Listening is the prime key of learning at all stages of education. Understanding the primary thoughts, realizing specific details, and forming interpretations are among the aims that listening accomplishes (Brown, 2006). Furthermore, in order for students to reach higher levels of thinking that help them to succeed in school; they need to 
develop their listening comprehension skills (Armstrong \& Rentz, 2002).

Listening aids students to realize, comprehend, interpret and communicate with their classmates (Rost, 2009). Jafari and Hashim (2015) assured that approximately half of the time should be dedicated to listening inside classrooms as it is the comprehensible tool of learning a foreign language. Listening is a dynamic reception of what is said as students may ask for repetition or retelling. The listeners' capability to comprehend the utterer's accent, intonation, syntax, and expressions define the degree of their listening comprehension (EI-Basel, 2008). Vandergrift (2004) and Walker (2014) revealed that the spoken input ought to be processed immediately by students in order for them to be able to access it another time. Listening comprehension development involves students' capability to interpret and respond to the spoken input using a variety of listening strategies and processes. Adrian (1993, as cited in Armstrong \& Rentz, 2002) believed that the problems of listening result from the lack of the capability to interpret the oral input since as has been assured by the researcher only $50 \%$ of the spoken language is heard and mostly misinterpreted by students. Listening comprehension process involves understanding meaning, interpreting syntax and vocab, realizing implied meaning, drawing conclusions, understanding pronunciation and intonation (Vandergrift, 1999; Armstrong \& Rentz, 2002; Brown, 2006; EI-Basel, 2008; Wang, 2011). Rost (2002) defined listening skill as a process of constructing meaning to what is said through involvement, discussion and interaction with the speaker. Listening skills operationally defined as energetic process of distinguishing, recognizing, interpreting, identifying and replying to what is said.
Schemata are constructing meaning to the text through relating new information to the previous knowledge of that topic. The listener succeeds in comprehending the text if the new information coordinated with the schemata (Rumelhart, 1980). According to that description of schemata, there are three strategies of processing information: bottom-up, top-down and interactive process. Bottom-up process of information is a strategy stimulated and triggered by bottom-level schema fitting of new information whereas top-down process of information is a strategy in which listeners use their prior knowledge to interpret the text and use various top-down strategies that include explaining, guessing, and drawing conclusion (Tsui \& Fullilove, 1998; Abdalhamid, 2012). In Abdalhamid (2012) study that examined university students' use of listening strategies, it was found that the development of listening comprehension was due to the use of a variety of listening strategies that include top-down and bottom-up strategies. This finding indicates that top-down and bottomup strategies are associated. The listeners' prior knowledge of a text helps them to interpret and guess. These interpretations and predictions are demonstrated and confirmed by the new information included in the text (Rubin, 1994).

\section{Listening Comprehension Difficulties}

According to Azmi et al. (2014), students' comprehension skills and motivation towards listening are increased if the text is familiar to them. Among the factors that cause listening difficulties are difficult vocab and syntax (Graham, 2006) According to Seferoglu and Uzakgoren (2004), some listening resources cause listening comprehension difficulties. Buck (2001) Hasan (2000) Vandergrift (2007) Bloomfield et al. (2010) and Walker (2014) found that difficult grammatical structures, unfamiliar words and themes, stress, accent and intonation, in addition to the text length 
are among the reasons that create comprehension problems. They assured that lack of interest and motivation cause students' listening comprehension difficulties as well.

Listening comprehension is difficult when students listen to recordings, i.e. they listen to a spoken text without watching the speaker since the speaker's body movement and face expressions help in listening comprehension process. Hasan (2000) conducted a study on 81 intermediate EFL students to identify listening comprehension problems in Syria and reached to the conclusion that the clarity of the spoken language played a crucial role in listening comprehension. In a research conducted on EFL students at Al Yarmouk University, Ja'fr (2013) realized that English accent, colloquial expressions, pronunciation, lack of time, fast rate of speech, unknown vocab and structure were the problems that hindered EFL learners in listening comprehension. Furthermore, just as the previously mentioned factors are related to the speaker, there are still other factors that would cause a break in listening comprehension. For example, different speakers use different accents, which is not easy for students to understand. Moreover, speakers mostly use colloquial language that is not taught at the school context. Golchi (2012) realized that older students in his study were better in listening comprehension than younger ones. The researcher referred this to the fact that the more students were exposed to the language and to training, the better they were in listening comprehension. Age has a positive correlation with listening comprehension. King \& Behnke (2003) stated that anxiety levels during listening activities impaired listening comprehension. Students' feelings were negatively affected while listening to the audio script, and their anxiety decreased when the listening task was about to finish. Moreover, those negative feelings led to disliking the listening task and accordingly not concentrating on what is being spoken.

A number of researchers (e.g., Hasan, 2000; Buck, 2001; Vandergrift, 2004 \& 2007; Bloomfield et al., 2010; Ja'fr, 2013; Walker, 2014; Azmi et. al., 2014; Jafari and Hashim, 2015) studied listening comprehension difficulties. They classified the difficulties encountered by students to several factors related to linguistic features of the language, the listener, the speaker, the content of the listening text and the physical setting where students listen. Moreover, they assured that students cannot always have words repeated which cause listening comprehension problems. They concluded that using prior knowledge, familiar texts in addition to motivation make communication easier. Hamouda (2013) emphasized that students can overcome their comprehension difficulties if they receive training on how to use listening comprehension strategies. Additionally, Hashwani, (2008) assured that motivation has positive effects on manipulating students' attitudes and anxiety levels towards learning and developing the English language skills.

Having on mind all listening comprehension difficulties that encountered by students, the purpose of the current study is to develop students listening comprehension and motivation using shadow-reading strategy which depends on communication between the student who reads a text and the shadower who retell what is heard.

\section{Listening Comprehension Motivation}

Foreign language learning students' need and desire to learn are crucial factors that increase their listening comprehension motivation. Motlhaka, (2012) investigated learning and teaching strategies that enhance students' motivation and its effect on developing listening skills. The researcher collected published articles and books and analyzed them. The findings of 
the study revealed that learners' autonomy is effective to enhance motivation. The researcher also suggests that cooperative activities promote developing learners' listening skills. Bahous, (2011) found that using teaching strategies may help students to learn and to have a positive effect on motivating learners and have more positive attitudes towards it.

Motivation has held researchers' interest for decades in language learning. Motivation has been defined as a "combination of effort plus desire to achieve the goal of learning the language plus favorable attitudes towards learning the language" (Gardner, 1985, p.10). In this study, listening comprehension motivation operationally defined as students desire to practice shadow reading strategy in order to improve their listening comprehension skills.

There are three types of motivation, initial attitudinal motivation (i.e., the initial attitudes toward studying English when they start shadowing training), motivation for listening (i.e., the motivation learners have for improving listening skills), and general motivation (i.e., the motivation learners have toward English generally). Intrinsic, integrative and instrumental motivation have been considered as significant aspects in English language development because students do efforts to develop English language skills (Motlhaka, 2012). It is crucial for students to have motivation and desire to be able to overcome any difficulties they may encounter during leaning the language (Kumaravadivelu, 2006).

Instrumental motivation depends on personal willingness and the desire to achieve something and an individual student's desire to learn English (Engin, 2009). Integrative motivation is a general interest and curiosity about language learning. Integrative and instrumental motivations are positively related; Students who have curiosity about learning language undeniably have a desire to develop that language (Motlhaka, 2012). Van Lier (1988) defined intrinsic motivation as a feeling of delight that results from participation in language learning activities. Accordingly, motivation might arise from students' interaction that makes them feel delighted and satisfied during practicing the language learning activities (Motlhaka, 2012). Recently, motivation studies have moved toward motivational self-system which conceptualizes learning motivation within a "self" framework. Taguchi, Magid, and Papi (2009) examined the selfmotivational system in Asian EFL contexts with 5000 students. They found that attitudes toward learning English play a positive role for EFL learners.

The above mentioned finding, when applied to shadowing training, predicts that students with initial positive attitudes towards improving listening will put forward greater efforts in shadowing and presumably improve their listening comprehension skills more than their counterparts with initial negative attitudes. Moreover, the discussion of intrinsic, instrumental and integrative motivation proves that students' interest and curiosity about learning English language help them develop the language skills and achieve positive academic goals. Consequently, it is assumed that shadow reading strategy inside listening classroom motivates students towards developing their listening skills as shadowing activities are learnercentered and students interactions during these activities arise their feeling of delight.

\section{The Theoretical Basis of Shadow \\ Reading Strategy}

The core of shadow-reading is repetition that improves language learning skills. Murphey (2001) assumed that shadowing is a stage between being other-controlled and self-controlled. When students repeat and retell the speech, they use their own words 
and expressions and become able to produce and control their output and when they fail to retell and repeat precisely, they communicate with the shadower and ask questions which enable them to have control over the shadower. Imitation is purposeful and meaningful activity inside foreign language classrooms (Brown, 2014). According to (de Guerrero \& Commander, 2013) shadow-reading strategy is an activity in which students assist each other in reading a text through interactive retelling, reading, repeating and summarizing. Students not only repeat the same text but also they exert an effort to use their own language and expressions.

Kadota (2007) explains shadowing from a scientific point of view. According to Kadota, when students hear a language, they understand it through two stages: the perception stage and the comprehension stage. First, in the perception stage, students distinguish the voice entering their ears. In this perception stage, students perceive the sound. Then almost at the same time, in the comprehension stage, students process the sound using five types of processing: lexical, syntactic, semantic, contextual, and schematic. In their first language, students understand meaning by using those types of processing as soon as they hear the sound because the comprehension stage is automatized. However, in second language learning, before perception becomes perfect, students have to rely on these five types of processing much more in the comprehension stage than in our first language. And if students spend too much time and attention on them, it is difficult to improve listening ability. However, shadowing can keep the perception switch always on and make the comprehension stage automatic (Segalowitz, 2005), which is similar to the process in the first language.
A number of researchers (e.g., Saito, Nagasawa, \& Ishikawa, 2011; Wiltshier, 2007; Zakeri, 2014) have found that shadowing has had a positive impact on listening comprehension. Tamai (1997) defined shadowing as an active in which students track the heard speech and repeat it as clearly as possible while they simultaneously listen. Shadow reading strategy operationally defined as educational activity in which shadower student is motivated to listen to hisher classmate to recognize, interpret, identify and imitate what is said with the aim of developing listening comprehension.

Shadowing can be effective because it focuses listeners' attention on the prosodic features of speech such as intonation, rhythm, and stress. It is effective because it improves listening ability, ability to repeat information, and reading speed at the same time (Kadota, 2007). Other researchers have also shown the effectiveness of shadowing. For example, in Tamai's (2005) research, the experimental group who practiced shadowing for 50 minutes 13 times made greater progress in listening, repeating, and reading than the control group which had dictation practice instead of shadowing. In other research by Mochizuki (2004), 58 junior high school students who practiced shadowing for 20 minutes 13 times achieved improved test results. As the results of the research indicate, it can be expected that shadowing will be effective for developing listening comprehension.

Shadow reading offers several opportunities for hearing, understanding and producing a text. It provides students with the chance to monitor each other's output, make modifications, improvements and corrections, and help each other comprehend and produce their own output using their expressions. Accordingly, the interactions among students, imitation and retelling included in shadow reading 
strategy develop students' intellectual skills that supposed to add to improving their language skills.

Shadow Reading Strategy for Developing Listening Comprehension and

\section{Motivation}

Flowerdew and Miller (2005) categorized listening strategies into three types: Cognitive strategies, which are the processes students depend to acquire the language; socio-affective strategies, which are the ways in which students use to enhance their learning and encourage themselves to continue learning; and metacognitive strategies, which are the ways students organize, monitor, and evaluate their learning. In terms of socio-affective strategies, pair work during shadowing can lower students' anxiety level and increase their motivation because it takes the focus off the students and places it on the heard text. Socio-affective strategies are the cooperative practices and activities used by students that increase their understanding and comprehension and decrease their anxiety (Vandergrift, 2003, Wilson, 2003 and Abdalhamid, 2012). Habte-Gabr (2006) acknowledged that in in order to develop their listening skills, students ought to be familiar with activities that reduce anxiety, raise motivation, and make them feel selfassured since listening strategies have positive effect on students as assured by Goh and Yusnita (2006) and Al-Alwan, Asassfeh, and Al-Shboul (2013). The impact of listening strategy use on EFL students' proficiency was investigated in a study carried by Mohseny and Raeisi (2009). It was found that students' strategy use has a positive impact on their performance. That result was assured by Bidabadi and Yamat (2011). They found that students listening strategies positively affect their listening skills performance.

With regard to the positive effect of shadow reading strategy on developing students listening comprehension skills,
Tamai (2005) examined performance of students using shadowing group and dictation group. The researcher found that shadow reading strategy positively affected students comprehension and performance level. Following the same line, Onaha (2004) found that shadow reading strategy was effective in developing EFL university students listening comprehension skills. Moreover, Mochizuki (2006) and Suzuki (2007) emphasized the significant effect of shadow reading in developing EFL students' comprehension. Toda and Liu's (2007) investigated shadow reading contexts and recommended reading material that can be divided into two parts and concluded that these materials should be read with pauses and appropriate speed in order for students to retell and comprehend them.

The mentioned studies prove that shadow reading strategy has a significant impact on promoting bottom-up listening processes. Additionally, students are capable of developing their listening comprehension skills inside shadow reading activities classrooms.

Regarding the positive effect of shadow reading strategy on listening motivation and whether learners' initial attitudinal motivation affects the improvement of listening skills and how learners' selfconfidence and motivation for listening and perceptions toward shadowing affects their improvement in listening, Hamada (2015) acknowledged that shadow reading strategy reduce students anxiety and increase their motivation. Li-Chi (2009) examined the effect of shadow reading on EFL students. The researcher confirmed that shadow reading positively stimulated students' attitudes, self-confidence and that students were satisfied with the strategy activities as a technique for enhancing their comprehension. 
To sum up, as seen above, the literature confirm that in terms of the mechanism of shadowing, students can improve their listening comprehension skills through shadowing training; in terms of motivation, those who hold a negative attitude toward learning English do not improve as much as their counterparts with positive attitudes. Thus, learners who have positive attitudes toward English are supposedly committed to shadowing eagerly; those who have less positive attitudes would not be less committed despite the assured theoretical benefit that they will gain from the training. In this case, those who have initial low attitudinal motivation will not benefit from shadowing practice. In order to attract a larger number of publicity, there is a pressing need to investigate how shadow reading strategy should be implemented, taking into account students' motivation.

\section{Methodology}

\section{Participants}

A sample of students from Mansoura Elthanawya Elgdeeda secondary school was selected and assigned randomly to an experimental group $(\mathrm{N}=33)$, and a control one. Students' age ranged from fifteen to sixteen years. The instructress of the experimental group was the researcher herself.

\section{Design}

Adopting the quasi-experimental scheme, the experimental and control group were pre-tested on the listening comprehension skills and received pre application of listening motivation scale. The experimental group was taught the shadow reading strategy, while the control group received the regular teaching. Both groups received the post application of the listening comprehension test and listening motivation scale to measure improvement in students' listening comprehension skills and listening motivation.

\section{Instruments}

For accomplishing the targets of the study, the researcher constructed the following instruments:

1)- Listening comprehension skills checklist.

2)- Listening comprehension skills test.

3)- Listening motivation scale.

Validity of the instruments was established through jury validation. Alpha Cronbach was used to measure the amount of internal consistency for the listening comprehension test and listening motivation scale. The value of alpha coefficient for the test was 0.742 , which means that the test is reliable. The value of alpha coefficient of the listening motivation scale was 0.773 , which indicates a high value of the scale reliability.

The Treatment: Shadow Reading Strategy for Developing EFL Students Listening Comprehension Skills and Motivation

Objectives

Based on the literature and related studies review, listening comprehension skills checklist, a training program was constructed to increase students' listening comprehension skills and listening motivation. The program aims at improving the following skills:

1- Developing secondary school students' listening comprehension skills.

2- Developing secondary school students' listening motivation.

\section{Description, Duration and Content}

The program was designed based on the shadow reading strategy for the experimental group. The program consisted of ten sessions. Each session was 45 minutes alongside one semester. The application of the program lasted for 10 weeks (September, October, November and December) during the academic year 2017 /2018 from 25/9/ 2017 till 11/12/2017. 


\section{Evaluation}

Students were told that they will be evaluated according to their contribution and participation in shadow reading. Students were given comments, suggestions and questions that helped them develop imitation and are also encouraged to write any difficulties they face.

\section{Results and Discussion}

It was hypothesized that there is

Table 1: Comparing the listening comprehension skills of the control and experimental group on the post test.

\begin{tabular}{|c|c|c|c|c|c|c|c|c|}
\hline \multirow{2}{*}{$\begin{array}{c}\text { Listening } \\
\text { comprehension skills }\end{array}$} & \multirow[t]{2}{*}{ Groups } & \multirow[t]{2}{*}{$\mathbf{N}$} & \multirow[t]{2}{*}{ Mean } & \multirow{2}{*}{$\begin{array}{c}\text { Std. } \\
\text { Deviation }\end{array}$} & \multirow{2}{*}{$\begin{array}{l}\text { Std. } \\
\text { error } \\
\text { mean }\end{array}$} & \multicolumn{3}{|c|}{$\begin{array}{c}\text { t-test for the } \\
\text { equality of mean }\end{array}$} \\
\hline & & & & & & $t$ value & df & sig \\
\hline \multirow{2}{*}{$\begin{array}{l}\text { 1-Retaining relevant } \\
\text { points through note- } \\
\text { taking. }\end{array}$} & Experimental & 33 & 14.43 & .97021 & .13143 & \multirow[t]{2}{*}{9.508} & \multirow[t]{2}{*}{64} & \multirow[t]{2}{*}{.001} \\
\hline & Control & & 10.21 & 2.76943 & .43481 & & & \\
\hline \multirow{2}{*}{$\begin{array}{l}\text { 2-Identifying the } \\
\text { reader's (shadower) } \\
\text { feeling. }\end{array}$} & Experimental & 33 & 14.73 & 1.17520 & .18321 & \multirow[t]{2}{*}{8.150} & \multirow[t]{2}{*}{64} & \multirow[t]{2}{*}{.001} \\
\hline & Control & & 11.40 & 2.67105 & .49057 & & & \\
\hline \multirow{2}{*}{$\begin{array}{l}\text { 3-Identifying the main } \\
\text { ideas. }\end{array}$} & Experimental & 33 & 10.90 & 1.51094 & .21091 & \multirow[t]{2}{*}{9.041} & \multirow[t]{2}{*}{64} & \multirow[t]{2}{*}{.001} \\
\hline & Control & & 6.78 & 2.76320 & .50324 & & & \\
\hline \multirow{2}{*}{$\begin{array}{l}\text { 4-Asking questions to } \\
\text { clarify the meaning. }\end{array}$} & Experimental & 33 & 10.17 & 1.10839 & .29086 & \multirow[t]{2}{*}{9.023} & \multirow[t]{2}{*}{64} & \multirow[t]{2}{*}{.001} \\
\hline & Control & & 7.109 & 2.14302 & .40872 & & & \\
\hline \multirow{2}{*}{$\begin{array}{l}\text { 5-Making correct } \\
\text { inferences from what is } \\
\text { listened to. }\end{array}$} & Experimental & 33 & 11.58 & 1.98305 & .18704 & \multirow[t]{2}{*}{8.329} & \multirow[t]{2}{*}{64} & \multirow[t]{2}{*}{.001} \\
\hline & Control & & 7.603 & 2.60981 & .39087 & & & \\
\hline \multirow{2}{*}{$\begin{array}{l}\text { 6- Distinguishing } \\
\text { between literal and } \\
\text { implied }\end{array}$} & Experimental & 33 & 12.98 & 1.49012 & .20041 & \multirow[t]{2}{*}{7.152} & \multirow[t]{2}{*}{64} & \multirow[t]{2}{*}{.001} \\
\hline & Control & & 7.93 & 2.70438 & .29875 & & & \\
\hline \multirow{2}{*}{ Total } & Experimental & 33 & 61.87 & 4.20589 & .70487 & \multirow[t]{2}{*}{9.678} & \multirow[t]{2}{*}{64} & \multirow[t]{2}{*}{.001} \\
\hline & Control & & 42.76 & 10.50870 & 1.8964 & & & \\
\hline
\end{tabular}

Results in table 1 shows that the mean score of the experimental group post-test is higher than that of the control group's mean score. It seems that the shadow reading strategy achieved better than the traditional method of teaching listening. The increase in students' level in the experimental group could be interpreted that students examine shadow reading strategy in which they were given limitless opportunities for listening, interpreting, understanding, repeating and retelling what they heard that in turn help them to develop their listening comprehension skills. This obtained result seems reasonable since shadow reading is characterized by listening carefully to the reader in order to retell what has been heard which requires students to comprehend, statistically significant difference between the mean score of the experimental and the control group on the post- administration of listening comprehension test favoring the experimental one. t-test was used to compare the differences between the mean scores of students in the listening comprehension test in the experimental and control group as shown in table 1 . interpret what they hear. These features of shadow reading strategy helped students to enhance their listening comprehension skills. This Result coincides with those achieved in the studies of Mochizuki (2006), Toda and Liu (2007), Brown (2014) and de Guerrero \& Commander (2013) who assured that imitation and interactive reading in the shadow reading strategy help students to develop their listening comprehension skills.

It was hypothesized that there is statistically significant difference between the mean score of the experimental group on the pre- and post- administration of the listening comprehension test favoring the post administration scores. t-test was used summarize, use their own words, and 
to compare the differences between the

comprehension pre and post-test in the mean scores of students in the listening experimental group as shown in table 2.

Table 2: Comparing the listening comprehension skills of experimental group on the pre and post-test.

\begin{tabular}{|c|c|c|c|c|c|c|c|c|}
\hline \multirow{2}{*}{$\begin{array}{c}\text { Listening } \\
\text { comprehension skills }\end{array}$} & \multirow{2}{*}{ Groups } & \multirow{2}{*}{$\mathbf{N}$} & \multirow{2}{*}{ Mean } & \multirow{2}{*}{$\begin{array}{c}\text { Std. } \\
\text { Deviation }\end{array}$} & \multirow{2}{*}{$\begin{array}{l}\text { Std. } \\
\text { error } \\
\text { mean }\end{array}$} & \multicolumn{3}{|c|}{$\begin{array}{c}\text { t-test for the } \\
\text { equality of mean }\end{array}$} \\
\hline & & & & & & t value & df & sig \\
\hline \multirow{2}{*}{$\begin{array}{l}\text { 1-Retaining relevant } \\
\text { points through note- } \\
\text { taking. }\end{array}$} & Post-test & 33 & 14.43 & .97021 & .13143 & \multirow[b]{2}{*}{12.850} & \multirow[t]{2}{*}{64} & \multirow[t]{2}{*}{.001} \\
\hline & Pre-test & 33 & 9.89 & 2.74302 & .49430 & & & \\
\hline \multirow{2}{*}{$\begin{array}{l}\text { 2-Identifying the reader's } \\
\text { (shadower) feeling. }\end{array}$} & Post-test & 33 & 14.73 & 1.17520 & .13098 & \multirow[t]{2}{*}{16.387} & \multirow[t]{2}{*}{64} & \multirow[t]{2}{*}{.001} \\
\hline & Pre-test & 33 & 10.73 & 2.40723 & .57432 & & & \\
\hline \multirow{2}{*}{$\begin{array}{l}\text { 3-Identifying the main } \\
\text { ideas. }\end{array}$} & Post-test & 33 & 10.90 & 1.51094 & .21091 & \multirow[t]{2}{*}{17.098} & \multirow[t]{2}{*}{64} & \multirow[t]{2}{*}{.001} \\
\hline & Pre-test & 33 & 7.02 & 2.60982 & .49532 & & & \\
\hline \multirow{2}{*}{$\begin{array}{l}\text { 4-Asking questions to } \\
\text { clarify the meaning. }\end{array}$} & Post-test & 33 & 10.17 & 1.10839 & .29086 & \multirow[t]{2}{*}{13.539} & \multirow[t]{2}{*}{64} & \multirow[t]{2}{*}{.001} \\
\hline & Pre-test & 33 & 6.08 & 2.20865 & .47542 & & & \\
\hline \multirow{2}{*}{$\begin{array}{l}\text { 5-Making correct } \\
\text { inferences from what is } \\
\text { listened to. }\end{array}$} & Post-test & 33 & 11.58 & 1.98305 & .18704 & \multirow[t]{2}{*}{14.716} & \multirow[t]{2}{*}{64} & \multirow[t]{2}{*}{.001} \\
\hline & Pre-test & 33 & 8.00 & 2.95383 & .38043 & & & \\
\hline \multirow{2}{*}{$\begin{array}{l}6 \text { - Distinguishing } \\
\text { between literal and } \\
\text { implied }\end{array}$} & Post-test & 33 & 12.98 & 1.49012 & .20041 & \multirow[t]{2}{*}{13.105} & \multirow[t]{2}{*}{64} & \multirow[t]{2}{*}{.001} \\
\hline & Pre-test & 33 & 7.21 & 2.86032 & .27390 & & & \\
\hline \multirow{2}{*}{ Total } & Post-test & 33 & 61.87 & 4.20589 & .70487 & \multirow[t]{2}{*}{16.904} & \multirow[t]{2}{*}{64} & \multirow[t]{2}{*}{.001} \\
\hline & Pre-test & 33 & 40.08 & 9.84982 & 1.6209 & & & \\
\hline
\end{tabular}

Results in table 2 shows larger gains for the post administration of the experimental group. According to Murphey (2001), repetition is the heart of shadow-reading which in turn develops comprehension. The results of the current study support this idea in that meaningful imitation significantly affects learners' comprehension as when students repeat what is heard, they use their own expressions and gain the capability to control their output. According to the findings of this study, it is logically to state that shadow reading efficiently affected students so that they could take control of their perception which indicates that shadow reading helped students develop their listening comprehension skills. This result is consistent with studies of Saito, Nagasawa, \& Ishikawa (2011) Wiltshier (2007) and Zakeri (2014) who assured that the shadow reading strategy offers students a great number of opportunities for hearing, understanding, making corrections if necessary, retelling, controlling the output and producing a text. Moreover, Rost (2009) and Jafari and Hashim (2015) assured that listening is active reception of what is heard that involves students ability to comprehend in order to give meaning to what is heard which is the heart of shadow reading strategy. In the current study, the students engage in interactive reading activities that aimed at developing their listening comprehension skills through active reception of what is heard. In addition to Buck (2001) Hasan (2000) Vandergrift (2007) Bloomfield et al. (2010) and Walker (2014) who found that fast speech rate in addition to anonymous and unexperienced topics, vocab, and accents are among factors that cause listening comprehension problems. Additionally, they assured that lack of motivation cause students' listening comprehension difficulties. In the current study, using shadow reading strategy activities give students opportunities to repeat, imitate, listen carefully, control speech rate, be 
familiar with the topic and produce a text that in turn helped students to overcome listening comprehension difficulties.

Third hypothesis states that there is statistically significant difference between the mean score of the experimental group and the control group on the post

Table 3: Comparing the post administration of the motivation scale of the control and experimental group on.

\begin{tabular}{|c|c|c|c|c|c|}
\hline \multirow{2}{*}{$\begin{array}{c}\text { Listening } \\
\text { Comprehension } \\
\text { Motivation Scale }\end{array}$} & Groups & Mean & $\begin{array}{c}\text { Std. } \\
\text { Deviation }\end{array}$ & t value & Sig. \\
\cline { 2 - 6 } & Experiment & 21.803 & 1.87032 & \multirow{2}{*}{9.301} & 0.001 \\
\cline { 2 - 6 } & Control & 17.015 & 2.30861 & \\
\hline
\end{tabular}

Results in table 3 shows that there is statistically significant difference at 0.001 level between the attained mean score of the control group and that of the experimental group in favor of the experimental group on the post administration of the motivation scale. The increase in students' level in the experimental group could be interpreted that students were motivated to learn the language in addition to the interesting and motivation activities accompanied the shadow reading strategy activities. Therefore, those students already got intrinsic motivation enriched through the use of the shadow reading strategy. Implementation of the shadow reading strategy helps learners develop their

Table 4: Comparing the pre and post administration of the motivation scale of the experimental group.

\begin{tabular}{|c|c|c|c|c|c|}
\hline \multirow{3}{*}{$\begin{array}{c}\text { Listening } \\
\text { Comprehension } \\
\text { Motivation Scale }\end{array}$} & Groups & Mean & $\begin{array}{c}\text { Std. } \\
\text { Deviation }\end{array}$ & t value & Sig. \\
\hline & $\begin{array}{l}\text { Post- motivation } \\
\text { scale }\end{array}$ & 21.803 & 1.87032 & \multirow{2}{*}{8.968} & \multirow{2}{*}{0.001} \\
\hline & $\begin{array}{c}\text { Pre- motivation } \\
\text { scale }\end{array}$ & 16.980 & 2.58230 & & \\
\hline \multicolumn{2}{|c|}{$\begin{array}{l}\text { Results in table } 4 \text { shows that the mean score } \\
\text { of the experimental group post-test is } \\
\text { higher than that of the control group's mean } \\
\text { score. The increase in students' level in the } \\
\text { experimental group could be interpreted } \\
\text { that in the shadow reading strategy students } \\
\text { were responsible for learning activities }\end{array}$} & \multicolumn{4}{|c|}{$\begin{array}{l}\text { included in the shadow reading strategy tha } \\
\text { include retelling and imitation in whic } \\
\text { students controlled their output an } \\
\text { learning. In addition to the healthy teachin } \\
\text { environment accompanied to the shador } \\
\text { reading interactive activities that highl } \\
\text { motivated students. Moreover, engagin }\end{array}$} \\
\hline
\end{tabular}

motivation to achieve meaningful learning. This result goes in line with those studies of Li-Chi (2009) and Hamada (2015) who assured that the shadow reading strategy help students to have goals in learning that direct their efforts and develop their motivation.

It was hypothesized that there is statistically significant difference between the mean score of the experimental group on the pre- and post- administration of the motivation scale favoring the post administration scores. t-test was used to compare the differences between the mean scores of students in the pre and postadministration of the motivation scale as shown in table 4. 
students in authentic tasks provided them with experiences that helped them have a goal and desire to participate in shadow reading activities in order to develop their comprehension. This result goes in line with studies of Taguchi, Magid, and Papi (2009) and Motlhaka (2012) that assured that engaging students in intrinsically motivated activities which are learnercentered activities motivate students to develop their listening comprehension and learning. In the current study, Shadow reading strategy triggered motivation among learners since its activities are student-centered. According to this finding, it appears possible to confirm that shadowreading can be used as motivating means for providing a suitable context to maintain the sense of cooperation among students, to listen and repeat and help each other without anxiety or fear.

\section{Discussion}

As set at the beginning of the study, the aim of the current study was to examine the relationship between shadowing as a teaching technique and EFL learners listening comprehension as well as motivation. The statistical analysis of the results showed that the experimental group students managed to obtain significantly higher scores on the listening test than control group students implying that shadow reading strategy was effective in developing students listening comprehension skills and motivation. The reason behind the effectiveness of shadow reading could be attributed to the unique characteristics of this technique for teaching listening and motivating students. According to Tannen (2007), students unintentionally practice shadowing as a result of their human drive to imitate. Murphey (2001) also maintains that shadowing is a tool of recursion because it allows for repeating similar language items, from simple repetition, to reformulation, to new production. The results of this study were in line with those of Mochizuki (2006), Suzuki (2007) and de Guerrero \& Commander (2013) who found that shadow reading strategy has a positive effect on enhancing students' comprehension. Additionally, Hamada (2015) proved that shadow reading is an effective strategy in raising students' motivation and decreasing their anxiety. Another reason could be related to the proper way of shadowing presented and modeled by the researcher. The accurate application of such techniques requires teachers who are well trained and also aware of the correct use of techniques.

\section{Conclusions}

The study addressed the impact of using the shadow reading strategy on improving listening comprehension and motivation. Findings showed larger gains in the listening skills and motivation produced by intrinsic and extrinsic motivation activated by shadow reading strategy activities. The data gathered in this study showed that shadow reading strategy helped students enhancing their listening comprehension skills and motivation. Although aspects such as students' autonomy, self-confidence might affect the results as well, the current study and the related studies proved that shadow reading strategy is a mean to improve students' listening comprehension skills and motivation.

The current study examined motivation toward listening, separating it from motivation toward shadowing, but the concept might possibly be confusing for some students. In the future, narrowing the focus to motivation toward shadowing can provide precise perspectives. Moreover, upcoming studies are needed to explore the influence of shadow reading strategy on students' reading and speaking skills. Further studies needed to investigate classroom activities with regard to students' motivation and attitudes. Finally, further studies needed to test shadowing in contrast 
to other methods for improving listening comprehension skills.

\section{References}

1. Armstrong, S., \& Rentz, T. (2002). Improving Listening Skills and Motivation. Master of Arts Research Project, Saint Xavier University and Skylight Professional Development Field-Based Master's Program. Available

at
http://www.ericedu.org.eg.doi.468085 CS511269.

2. Anderson, N. J. (2009). ACTIVE reading: The research base for a pedagogical approach in the reading classroom. In Z. Han \& N. J. Anderson (Eds.), Second language reading research and instruction: Crossing the Boundaries (pp. 117143). Ann Arbor, MI: The University of Michigan Press.

3. Azmi, B. M., Celik, B., Yidliz, N., \& Tugrul, M. C. (2014). Listening Comprehension Difficulties Encountered by Students in Second language Learning Class. Journal of Educational and Instructional Studies in the World, 4(4), 1-6.

4. Abu-Essa, S. M. (2005). Using Two Strategies of Questioning for Developing the Listening Skills of English Department Students in Faculty of Education. Unpublished M.A Thesis, Faculty of Education at Damietta , Mansoura University.

5. Abdel-Latif, M. (2002). The Effect of Graded Rates of Delivery on Listening Comprehension among English Department Students. Unpublished M.A. Thesis, Faculty of Education, AlAzhar University.

6. Abdalhamid, F. (2012). Listening Comprehension Strategies of ArabicSpeaking ESL Learners. Master's Dissertation, Department of English, Colorado State University, Fort Collins, Colorado.
7. Al-Alwan, A., Asassfeh, S., \& AlShboul, Y. (2013). EFL Learners' Listening Comprehension and Awareness of Metacognitive Strategies: How Are They Related? International Education Studies, 6(9), 31-39.

8. Brown, H. D. (2014). Principles of language learning \& teaching (6th ed.). White Plains, NY: Pearson. Centeno-Cortés.

9. Booth, J. R., Perfetti, C. A., MacWhinney, B. (1999). Quick, automatic, and general activation of orthographic and phonological representations in young readers Developmental Psychology, 35, 3-19.

10. Booth, J. R., Perfetti, C. A., MacWhinney, B., Hunt, S. B. (2000). The association of rapid temporal perception with orthographic and phonological processing in reading impaired children and adults. Scientific Studies of Reading, (4), 101132.

11. Buck, G. (2003). Assessing Listening. Cambridge: Cambridge University Press.

12. Bloomfield, A. et al. (2010). What Makes Listening Difficult? Factors Affecting Second Language Listening Comprehension. Available at:http://www.google.es/url?sa=t\&rct= $\mathrm{i} \& \mathrm{q}=\&$ esrc $=$ s\&frm $=1 \&$ source $=$ web $\&$ cd=3\&ved=0CEgQFjAC\&url=http://w wwdliflc.edu/file.ashx?path\%3Darchi ve/documents/CASL_study_FINAL_ Lit_Rev.pdf\&ei=kFfMUu_vJ8PE0QX Vm4HoDg\&usg=AFQjCNGUJKIMD BEcB8vygOP4Hd2mh1uIQg

13. Buck, G. (2001). Assessing Listening. Cambridge: Cambridge University Press. Available at:http://dx.doi.org/10.1017/CBO9780 511732959.

14. Bidabadi, F., \& Yamat, H. (2011). The Relationship between Listening 
Strategies Used by Iranian EFL Freshman University Students and Their Listening Proficiency Levels. English Language Teaching, 4(1), 2632.

15. Brown S., (2006). Teaching Listening. Cambridge: Cambridge University Press.

16. Bernaus, M.; Gardner, R.C. (2008). Teacher motivation strategies, student perceptions, student motivation, and English achievement. Mod. Lang. J., (92), 378-401.

17. Bahous, R (2012) motivating students in the EFL classroom: A case study of perspectives vol (4) no.(3), 2011

18. Coskun, Abdullah (2010). "The Effect of Metacognitive Strategy Training on the Listening Performance of Beginner Students." Research on Youth and Language, 4(1): 35-50.

19. de Guerrero, M., \& Commander, M. (2013). Shadow-reading: Affordances for imitation in the language classroom. Language Teaching Research.

20. El-Basel, R. M. (2008). The Effectiveness of Multimedia Program Using Animation to Develop the Speaking Skill in English for the Pupils of the Primary Stage. MA Thesis, Cairo University, Institute of Educational Studies.

21. Engin, A. O. (2009). Second language learning success and motivation. Social Behaviour and Personality, 37(8), 1035-1042. Doi: 10.2224/sbp.2009.37.8.1035

22. Flowerdew, J. \& Miller, L. (2005). Second language listening. New York: Cambridge University Press.

23. Goh, C. (2008). Metacognitive instruction for second language listening development: Theory, practice and research implications. RELC journal, 39(2), 188-213. Available https://doi.org/10.1177/003368820809 2184.

24. Goh, C., \& Taib, Y. (2006). Metacognitive instruction in listening for young learners. ELT Journal, 60(3), 222-232.

25. Goodnough, K. (2001). Multiple intelligences theory: A Framework for personalizing science curricula. Journal of school science and Mathematics, 101(4), 180-193.

26. Guerrero, M., \& Commander, M. (2013). Shadow-reading: Affordances for imitation in the language classroom. Language Teaching Research.

27. Goh, C. and Yusnita ,T. (2006) Metacognitive Instruction in Listening for Young_Learners. ELT Journal, 60 (3): 222-232.

28. Graham, S. (2006). Listening Comprehension: The Learners' Perspective. System, (34), 165-182.

29. Glochi, M. (2012). Listening Anxiety and Its Relationship with Listening Strategy Use and Listening Comprehension among Iranian IELTS Learners. International Journal of English Linguistics, ISSN 1923-8703 (Online), 2 (4).

30. Gardner, R.C.(1985). Social Psychology and Second Language Learning; Edward Arnold: London, UK.

31. Hasan, A. (2000). Learners' Perceptions of Listening Comprehension Problems. Language, Culture and Curriculum. (13), 137152.

32. Hamada, Y. (2015). Uncovering Shadowing as an EFL Teaching Technique for Listening: Learners' perceptions, self-confidence, and motivation. Akita University Annual Report on General Education Research, pp. 9-22. Available at: http://air.lib.akita-u.ac.jp/dspace/ 
bitstream/10295/2779/1/kkiso17(9).pd $\mathrm{f}$

33. Habte-Gabr, E. (2006). The Importance of Socio-affective Strategies in Using EFL for Teaching Mainstream Subjects. Journal of Humanizing Language Teaching, 8(5). Available at: http://www.hltmag.co.uk/sep06/sart02 .htm\#C1

34. Hamouda, A. (2013). An Investigation of Listening Comprehension Problems Encountered by Saudi Students in the EL Listening Classroom. International Journal of Academic Research in Progressive Education and Development, 2(2), 113-15.

35. Hasan, A. (2000). Learners' Perceptions of Listening Comprehension Problems. Language, Culture and Curriculum, (13), 137153.

36. Haley, H. M. (2004). LearnerCentered Instruction and the Theory of Multiple Intelligences with Second Language Learners. Teachers College Record, 106(1), 163-180.

37. Hashwani, M. S. (2008). Students' attitudes, motivation and anxiety towards English language learning. Journal of Research and Reflections in Education, 2(2).

38. Ja'fr, Sh. (2013). Listening Comprehension for first Grade Students of Department of English Language Arts at AL-Yarmouk University College. Diyala Journal, 58.

39. Jafari, K., \& Hashim, F. (2015). Comparison of Normal and Moderately Slow Speech Rates: Listening to Students' Voices in Listening Comprehension Classes in EFL Context. International Journal of Foreign Language Teaching in the Islamic World, 3(3), 5-11.
40. Kallenbach, S., \& Viens, J. (2002). Open to Interpretation: Multiple Intelligences Theory in Adult Literacy Education. Teachers College Record, 106(1), 58-66.

41. Kern, R. (2000). Literacy and Language Teaching. Oxford: Oxford University Press.

42. Kadota, S. (2007). Shadowing and the science of reading. Tokyo: Kosumopia K.K.

43. Kok, I. (2010). The relationship between students' reading comprehension achievement and their attitudes towards learning English and their abilities to use reading strategies with regard to hemispheric dominance. Procedia Social Behavioral Sciences, (3), 144-151.

44. Kumaravadivelu, B. (2006). Understanding Language teaching: From method to Post method. London, UK: Lawrence Erlbaum Associates.

45. Li-Chi, L.(2009). A Study of Using Shadowing As a Task in Junior High School EFL Program in Taiwan; National Taiwan University of Science and Technology: Taipei, Taiwan.

46. Motlhaka, H (2012) developing ESL listening, promoting student motivation. M.A thesis, Indiana university of Pennsylvania.

47. Murphey, T. (2001). Exploring conversational shadowing. Language Teaching Research, 5, 128-155.

48. Mochizuki, M. (2004). Exploring the application of shadowing to Japanese education. Audio-Visual Education. 6, 37-53.

49. Murphey, T. (2001). Exploring conversational shadowing. Language Teaching Research, (5), 128-155. Available at:http://dx.doi.org/10.1177/13621688 $\underline{0100500203}$ 
50. Myxter, J. (2014). The Effects of Flipping the Classroom on Classroom Environment and Student Achievement (Doctoral dissertation, Minot State University).

51. Mohseny, A., \& Raeisi, N. (2009). The Relationship between Language Proficiency of EFL Students and Their Strategy Use in Listening Comprehension. TEFLL, 1(4), 111132.

52. Noels, K.A. Learning Japanese; Learning English: Promoting Motivation Through Autonomy, Competence and Relatedness. In Language Learning Motivation in Japan; Apple, M.T., Da Silva, D., Fellner, T., Eds.; Multilingual Matters: Bristol, UK, 2013; pp. 15-34.

53. Nakanishi, T., \& Ueda, A. (2011) Extensive reading and the effect of shadowing. Reading in a Foreign Language, 23, 1-16.

54. Onaha, H. (2004). Effect of shadowing and dictation on listening comprehension ability of Japanese EFL learners based on the theory of working memory. JACET Bulletin, 39 , 137-148.

55. Osada, N. (2004). Listening Comprehension Research: A Brief Review of the Last Thirty Years. 2004 TALK, Japan.

56. Phuong, L. L. T. (2011). Adopting CALL to Promote Listening Skills for EFL Learners in Vietnamese Universities. In International Conference-ICT for Language Learning

57. Rost, M. (2002). Teaching and Researching Listening. London, UK: Longman.

58. Rubin, J. (1994). A review of second language listening comprehension research. The Modern Language Journal, 78: 199-221.
59. Rumelhart, D. (1980). Schema: The basic building blocks of cognition. In: R. Spiro, B. Brice \& W. Brewer. (Eds.), Theoretical issues in reading comprehension, Hillsdale, NJ: Erlbaum.

60. Ryan, R. M., \& Deci, E. L. (2000). Self-determination theory and the facilitation of intrinsic motivation, social development, and well-being. American Psychologist,55 (1), 68-78.

61. Rost, M. (2009). Teacher Development Interactive: Listening. White Plains. NY: Pearson Longman.

62. Seferoglu, G., \& Uzakgoren, S. (2004). Equipping Learners with Listening Strategies in English Language Classes. Hacettepe University Faculty of Educational Journal, 27, 223-231.

63. Scapens, M. (2007). Implementing the theory of multiple intelligences in the junior secondary school. Master of Education. The University of Waikato.

64. Saito, Y., Nagasawa, Y., \& Ishikawa, S. (2011). Effective instruction of shadowing using a movie. In A.Stewart (Ed.), JALT2010 Conference Proceedings. Tokyo: JALT.

65. Segalowitz, N. (2005). Automaticity and second languages. In C. Doughty \& M. H. Long, (Eds.), The handbook of Second Language Acquisition (pp. 382-408). Oxford: Blackwell.

66. Suzuki, K. (2007). Investigation on the instruction for listening comprehension through shadowing. STEP Bulletin, 19, 112-124.

67. Toda, T., \& Liu, J. (2007). Basic research for the establishment of a shadowing course. Japanese language education methods, 14(1), 8-9.

68. Taguchi, T., Magid, M. \&Papi, M (2009). The L2 motivational self system among Japanese, chinese and 
Iranian learners ofEnglish: A comparative study. In Dörnyei, Z. and Ushioda, E. (eds), Motivation, Language Identity and the L2 Self. Bristol: Multilingual Matters (pp. 6667).

69. Tamai, K. (1997). The effectiveness of shadowing and listening process. Current English Studies, 36, 105$116 . \mathrm{m}$

70. Tamai, K. (2005). Research on the effect of shadowing as a listening instruction method. Tokyo: Kazama.

71. Tsui, A. B. M., \& Fullilove, J. (1998). Bottom-up or Top-down Processing as a Discriminator of L2 Listening Performance. Applied Linguistics, 19(4), 432-451.

72. Tannen, Deborah. 2007. Talking Voices. Repetition, Dialogue, and Imagery in Conversational Discourse (2nd ed.). Cambridge, UK: Cambridge University Press.

73. Vandergrift, L. (1999). Facilitating second language listening comprehension: Acquiring successful strategies. ELT Journal, 53(3), 168176.

74. Vygotsky, L. S. (1986). Thought and language. Cambridge, MA: MIT Press.

75. Vandergrift, L. (2003). Orchestrating Strategy Use: Towards a Model of the Skilled L2 Listener. Language learning, 53, 461-491. http://dx.doi.org/10.1111/14679922.00232

76. Vandergrift, L. (2004). Listening to Learn or Learning to Listen? In Cambridge University Press (Ed.), Annual Review of Applied Linguistics (2004) (pp. 3-25) Cambridge

\section{University Press, USA. http://dx.doi.org/10.1017/S026719050 4000017}

77. Vandergrift, L. (2007). Recent Development in Second Language Listening Comprehension Research. In Graeme Porte (Ed.), Language Teaching: Surveys and Studies. (pp. 291-210) Cambridge University Press, Canada.

78. Van Lier, L. (1988). The classroom and the language learner. London, UK: Longman.

79. Vandergrift, L. (2011). Second Language Listening: Presage, Process, Product and Pedagogy. In: Hinkel, E. (ed.) Handbook of research in second language teaching and learning. 2nd Ed. New York: Routledge, 455-471.

80. Wang, H. (2011). Conversational Implicature in English Listening Comprehension. Journal of Language Teaching and Research, 2(5), 11621167.

81. Walker, N. (2014). Listening: the Most Difficult Skill to Teach. Encuentro, 23, 167-175.

82. Wilson, M. (2003). Discovery Listening-Improving Perceptual Processing. Available at: http://dx.doi.org/10.1093/elt/57.4.335

83. Wiltshier, J. (2007). Fluency through shadowing-What, why, and how? In K. Bradford-Watts (Ed.), JALT2006 Conference Proceedings. Tokyo: JALT.

84. Zakeri, E. (2014). The effect of shadowing on EFL learners' oral performance in terms of fluency. International Journal of English Language Teaching, 2(1), 21-26 